\title{
ANALISIS PENGADAAN ALAT KESEHATAN DI RUMAH SAKIT UMUM DAERAH PADANG PARIAMAN TAHUN 2017
}

\author{
Jon Kenedi ${ }^{1}$, Dasman Lanin², Zukarnain Agus $^{3}$
}

\begin{abstract}
Abstrak
Pengadaan alat kesehatan adalah usaha pihak manajemen logistik rumah sakit dalam pemenuhan kebutuhan rumah sakit dan user akan alat kesehatan untuk peningkatan mutu pelayanan rumah sakit. Untuk pemenuhan kebutuhan ini diperlukan pertimbangan efisiensi, efektifitas dan pemanfaatan alat kesehatan yang diadakan tersebut. RSUD Padang Pariaman masih bermasalah dalam pelaksanaan pengadaan alat kesehatan dimana masih adanya alat kesehatan yang diadakan belum dimanfaatkan dalam memberikan pelayanan kesehatan di rumah sakit. Penelitian ini bertujuan untuk melihat bagaimanakah analisis pengadaan alat kesehatan di RSUD Padang Pariaman tahun 2017. Hasil penelitian ini dari komponen input, kebijakan atau SOP belum ada, tenaga dari sisi kuantitas belum mencukupi, dana perlu ditingkatkan anggaranya terutama yang bersumber dari APBD, sarana prasarana belum ada. Pada komponen proses, perencanaan dan penerimaan/pemeriksaan masih ada masalah sedangkan pada komponen pengadaan pemilihan penyedia sudah sesuai dengan Perpres RI No 4 Tahun 2015. Pada komponen output, pelaksanaan pengadaan alat kesehatan di RSUD Padang Pariaman belum sepenuhnya sesuai dengan kebutuhan rumah sakit dan user.
\end{abstract}

Kata Kunci : Rumah Sakit, Alat Kesehatan, Perencanaan, Pengadaan dan penerimaan

\section{Abstract}

Procurement of medical equipment is the effort of the hospital's logistics management to fulfill the hospitals demands and users of health equipment to improve the hospital services. In fuiltiling this requireneed we need of efficiency, effectiveness and utilization of the medical devics. Regional Public Hospital in Padang Pariaman still has problem in the implementation of health equipment procurement where the existence of health equipment held not been utilized to provide health services in the hospital. This study aims to see how the analysis of procurement of health equipment in Regional Public Hospital in Padang Pariaman year 2017. Result of the research from input component, policy or Standard of Prosedure not yet exist, power from side of quantity not yet enough, fund need to increase its service especially that sourced from $A P B D$, means of infrastructure not yet exist. In the components of the process, planning and acceptance / examination is still problem while the procurement component provider selection is in Perpres RI No 4 of 2015. In the output component, the implementation of health equipment procurement in RSUD Padang Pariaman not fully in accordance with the hospital need and user

Keywords : Hospital, Health Equipment, Planning, Procurement and acceptance

Affiliasi penulis : 1. Rumah Sakit Umum Daerah Padang Pariaman 2. Ketua Program Studi Megister Administrasi Publik Universitas Negeri Padang. 3. Dosen IImu Gizi Fakultas Kedokteran Universitas Andalas.

Korespondensi : Jon Kenedi, E-mail: jonkenedi01@yahoo.co.id Hp. 081363219840

\section{PENDAHULUAN}

Rumah sakit adalah institusi pelayanan kesehatan yang menyelenggarakan pelayanan kesehatan perorangan secara paripurna yang menyediakan pelayanan rawat inap, rawat jalan dan gawat darurat. ${ }^{1}$ Dalam memberikan pelayanan kesehatan yang profesional, bermutu dan berkesinambungan rumah sakit perlu didukung dengan ketersedian alat kesehatan yang memenuhi standar, peralatan tersebut terdiri dari peralatan medis untuk instalasi gawat darurat, rawat jalan, rawat inap, rawat intensif, rawat operasi, persalinan, radiologi, laboratorium klinik, pelayanan darah, rehabilitasi medik, farmasi, instalasi gizi, dan kamar jenazah. $^{2}$

Untuk mendapatkan alat kesehatan yang sesuai kebutuhan, memenuhi standar dan optimal dalam pemanfaatan maka diperlukan manajemen logistik alat kesehatan yang baik. Manajemen logistik adalah proses pengelolaan yang strategis terhadap pemindahan dan penyimpanan barang, suku cadang dan barang jadi dari supplier, diantara fasitas perusahaan dan kepada para langanan. ${ }^{3}$ Sedangkan manajemen logistik di rumah sakit didefinisikan sebagai suatu proses pengolahan secara strategis terhadap pengadaan, penyimpanan, pendistribusian, pemantauan persediaan bahan (stock, material, supplies, inventory dan lain-lain) yang diperlukan bagi produksi jasa rumah sakit. ${ }^{4}$

Rumah Sakit Umum Daerah Padang Pariaman merupakan Rumah Sakit Umum Kelas C yang melakukan pelayanan kesehatan dan 
melaksanakan sistem rujukan bagi masyarakat Daerah Kabupaten Padang Pariaman. ${ }^{5}$ Untuk mencapai visi dan misinya dalam penyelenggaraan pelayanan kesehatan memerlukan Sumber Daya Manusia (SDM) yang berkualitas. Dalam memberikan pelayanan kesehatan diperlukan alat kesehatan yang sesuai standar, aman dan optimal pemanfaatan serta efisien. Untuk dapat mewujudkannya maka sangat diperlukan suatu manajemen logistik alat kesehatan yang baik. ${ }^{4}$

Pengelolaan manajemen logistik alat kesehatan yang baik, dengan memperhatikan rencana kebutuhan, skala prioritas, perencanaan pengembangan dan mengevaluasi manfaat bagi pelayanan kesehatan di rumah sakit tentunya Rumah Sakit Umum Daerah Padang Pariaman akan lebih sempurna dalam melakukan proses pengadaan alat kesehatan. Keberhasilan dalam perencanaan kebutuhan harus didukung oleh semua pihak, rencana yang dipaksakan akan sulit mendapatkan dukungan, bahkan sebaliknya akan berakibat tidak lancar dalam pelaksanaannya. ${ }^{6}$

Salah satu yang menjadi permasalahan pada pengelolaaan manajemen logistik alat kesehatan di RSUD Padang Pariaman berdasarkan observasi dan wawancara peneliti dengan Ka IPSRS tanggal 15 April 2017 adalah adanya alat kesehatan yang belum dimanfaatkan yang masih tersimpan digudang penyimpanan, dan adanya alat kesehatan yang sudah terpasang pada ruang tindakan atau instalasi akan tetapi belum di manfaatkan dalam memberikan pelayanan kesehatan di rumah sakit.

Berdasarkan wawancara dengan Kasi Sarana dan Prasarana Rumah Sakit adanya alat kesehatan yang belum di manfaatkan diakibatkan karena belum tersedia ruangan atau ruangan tidak memenuhi syarat untuk penempatan alat kesehatan tersebut seperti ruang ICU, Radiologi dan UTDRS. Untuk mengamankanya terpaksa dilakukan penyimpanan terlebih dahulu menunggu adanya persiapan ruangan dan faktor pendukung lainya.

Berdasarkan hasil observasi dan wawancara peneliti dengan Kepala Instalasi Pemeliharaan Sarana Prasarana Rumah Sakit (IPSRS) dan Kasi Sarana dan Prasarana tersebut kesimpulan awal peneliti adalah adanya permasalahan manajemen logistik pada proses pelaksanaan pengadaan alat kesehatan di RSUD Padang Pariaman. Proses pelaksanaan pengadaan alat kesehatan yang baik adalah pengadaan yang efektif dan efisien dan optimal dalam pemanfaatan alat kesehatan. ${ }^{7}$ Pengadaan alat kesehatan di fasilitas pelayanan kesehatan harus dapat termanfaatkan secara berhasil guna dan berdaya guna. ${ }^{8}$ Sementara dari manajemen logistik hal tersebut merupakan suatu kegagalan dalam proses pelaksanaan pengadaan alat kesehatan di RSUD Padang Pariaman.

Rumah Sakit Umum Daerah Padang Pariaman harus dapat melakukan manajemen logistik pengadaan alat kesehatan yang baik, untuk dapat memperoleh alat kesehatan yang memenuhi standar, sesuai kebutuhan rumah sakit atau user dan dapat termanfaatkan secara efektif dan efisien guna memberikan pelayanan kesehatan yang bermutu dan berkualitas pada masyarakat. Hal tersebut mendorong peneliti untuk melakukan penelitian tentang proses pelaksanaan pengadaan alat kesehatan di Rumah Sakit Umum Daerah Padang Pariaman.

Berdasarkan latar belakang yang telah di uraikan diatas, peneliti menyimpulkan adanya masalah pada proses pelaksanaan pengadaan alat kesehatan. Untuk itu perlu dilakukan analisis terhadap Proses Pelaksanaan Pengadaan Alat Kesehatan di Rumah Sakit Umum Daerah Padang Pariaman tahun 2017.

\section{METODE}

Penelitian ini menggunakan metode pendekatan kualitatif, dengan tujuan untuk menggali informasi mendalam tentang pengadaan alat kesehatan di Rumah Sakit Umum Daerah Padang Pariaman, dengan menggunakan pendekatan sistem. Pada sistem yang sedang berjalan disertai dengan wawancara mendalam dengan petugas yang terlibat dalam kegiatan pengadaan alat kesehatan pada Rumah Sakit Umum Daerah Padang Pariaman.Penelitian dilakukan bulan September s/d Oktober 2017 di Rumah Sakit Umum Daerah Padang Pariaman. Teknik penentuan informan dalam penelitian ini adalah dengan 
purposive sampling. Informan dalam penelitian ini adalah sebanyak lima belas orang yaitu: Direktur, Kabid Penunjang Medik, Kasi Perencanaan, Kasi pelayanan MediK, Kasi Sarana Prasarana, Pejabat Pembuat Komitmen, Pejabat pengadaan, Ketua tim penerima/pemeriksaan barang/jasa, Anggota tim teknik penerima barang/jasa,Penanggung jawab poli mata, Kepala instalasi laboratorium, Kepala instalasi radiologi, Kepala instalasi IGD, Kepala instalasi kamar operasi, Kepala poli fisioteraphy.

Pengumpulan data melalui observasi, wawancara mendalam, telaah dokumen dan Focus Group Discussion (FGD). Analisis data dengan membuat transkrip data, mereduksi data, penyajian data dan mengambil kesimpulan. Validasi data dengan triangulasi sumber dan triangulasi teknik.

\section{HASIL PENELITIAN}

\section{Komponen input}

a. Kebijakan (SOP)

Kebijakan (SOP) dalam pengadaan alat kesehatan di RSUD Padang Pariaman mengacu pada Klasifikasi dan Perizinan Rumah Sakit dan juga pada Sistem Pengadaan Barang dan Jasa Pemerintah. Namun RSUD Padang Pariaman belum menuangkan dalam bentuk operasional (SOP) atau protap dalam pelaksanaan pengadaan alat kesehatan.

\section{b. Sumber Daya Manusia}

Sumber daya manusia dalam pengadaan alat Kesehatan di RSUD Padang Pariaman 2017. bahwa secara kuantitas sumber daya manusia pelaksana pengadaan alat kesehatan di RSUD Padang Pariaman belum memenuhi kebutuhan, sedangkan secara kualitas sudah memenuhi kualifikasi sebagai petugas pelaksana pengadaan alat kesehatan.

\section{c. Dana}

Dana pelaksanaan pengadaan alat kesehatan sebahagian besar bersumber dari APBN melalui Kepmenkes yang berbentuk Dana Alokasi Kusus dan yang bersumber dari APBD berbentuk Dana Alokasi Umum (DAU) masih kurang.

\section{d. Sarana Prasarana}

Sarana dan prasarana dalam pelaksanaan pengadaan alat kesehatan belum tersedia, kegiatan proses pengadaan dilakukan dengan mengunakan sarana dan fasilitas yang ada pada masing-masing jabatan strukturalnya.

\section{Komponen Proses}

\section{a. Perencanaan}

Perencanaan penentuan kebutuhan dimulai dari permintaan kebutuhan dari masing-masing instalasi atau user direkap dan dibahas dengan bidang pelayanan, bidang penunjang, perencanaan dan tata usaha untuk menentukan prioritas berdasarkan pada permenkes nomor 56 tahun 2014, selanjutnya untuk yang mengunakan dan APBN atau DAK diajukan usulan prosposal ke bidang perencanaan untuk penyesuaian prioritas dengan menu alat kesehatan yang tersedia pada menu DAK, kalau tidak tersedia priotas kebutuhan rumah sakit pada menu tersebut akan dialihkan pada kebutuhan yang bukan prioritas yang tersedia pada menu pilihan alat kesehatan yang ada pada menu DAK.

\section{b. Pengadaan}

Pelaksanan pengadaan alat kesehatan di RSUD Padang Pariaman dilaksanakan setelah daftar pelaksanaan anggaran keluar, maka PPK medaftarkan rencana umum pengadaan ke unit layanan pengadaan (ULP) selanjutnya pejabat pembuat komitmen atau pejabat pengadaan melakukan pemilihan penyedia dengan EPurchasing melalui E-catalogue.

\section{c. Penerimaan}

Penerimaan/pemeriksaan dilakukan oleh panitia penerima yang salah satunya anggotanya mempuayai keahlian bidang eletromedik. Pemeriksaan diawali dengan instalisasi alat, pemeriksaan administrasi alat dan dilakukan uji fungsi alat.

\section{Komponen Output}

Masih adanya penyedian pengadaan alat kesehatan yang tidak sesuai dengan kebutuhan rumah sakit atau user dan masih adanya penyediaan alat kesehatan tersebut yang belum 
dapat dimanfaatkan dalam pelayanan kesehatan di RSUD Padang Pariaman.

\section{PEMBAHASAN}

\section{Komponen Input}

\section{a. Kebijakan (SOP)}

Kebijakan adalah peraturan atau pedoman sebagai acuan dalam pengadaan alat kesehatan di RSUD Padang pariaman. Hasil penelitian kebijakan dalam pelaksanaan Pengadaan alat kesehatan di RSUD Padang Pariaman berpedoman pada Klasifikasi dan Perizinan Rumah Sakit dan sistem Pengadaan Barang/Jasa Pemerintah. RSUD Padang Pariaman belum menuangkan lebih lanjut dalam kebijakan operasional Rumah Sakit baik berupa protap ataupun Standar Operasional Prosedur (SOP) dalam pelaksanaan pengadaan alat kesehatan di RSUD Padang Pariaman.

Hasil penelitian ini berbeda dengan penelitian yang menyatakan tata cara pelaksanaan pengadaan obat dan alat kesehatan di RSUD Kabupaten Sukoharjo sudah bisa dijadikan model pengadaan obat dan alat kesehatan bagi RSUDRSUD lainnya, karena patuh terhadap aturan yang berlaku dan sudah terstandarisasi dalam operasionalnya. ${ }^{9}$,

Standar Operasional Prosedur (SOP) merupakan prosedur kerja yang dilakukan secara benar dan konsisten, Standar Operasional Prosedur (SOP) merupakan serangkaian instruksi tertulis yang dibakukan mengenai berbagai proses penyelenggaraan aktivitas organisasi, bagaimana dan kapan harus dilakukan, dimana dan oleh siapa dilakukan. ${ }^{10}$ Dengan adanya Standar Operasional Prosedur (SOP) pelaksanaan pengadaan alat kesehatan oleh setiap petugas yang melaksanakan pengadaan akan menguranggi tingkat keselahan atau kelalaian, meningkatkan efisien dan efektifitas, menciptakan ukuran standar kinerja dan sebagai intrumen yang dapat melindunggi pelaksana dari kemungkinan tuntutan hukum, terarah dan tujuan dari pengadaan tersebut dapat tercapai dengan baik maka diupayakan.

Rumah Sakit perlu mengeluarkan petunjuk operasional sebagai pedoman. Tanpa adanya dukungan kebijakan dari manajemen maka pelaksaan pengadaan alat kesehatan tidak akan bisa terlaksana dengan baik karena kebijakan di sebuah rumah sakit merupakan dasar hukum untuk pelaksanaan sebuah kegiatan khsususnya dalam pengadaan alat kesehatan.

\section{b. Sumber Daya Manusia}

Pelaksanaan pengadaan alat kesehatan di RSUD Padang Pariaman ditemui bahwa pelaksanaan pengadaan alat kesehatan belum didukung dengan jumlah sumber daya manusia yang cukup. Namun dari segi kualitas sumber daya manusia untuk Pejabat Pembuat Komitmen dan Pejabat Pengadaan sudah memenuhi syarat yaitu telah memiliki sertifikat keahlian barang/jasa dan peryaratan manajerial lainya. ${ }^{11}$ Dan begitu juga sumber daya manusia tim penerima/pemeriksa juga sudah memehui secara kualitas yaitu sudah adanya satu orang tenaga ahli eletromedik dalam tim penerima/pemeriksa hasil pengadaan alat kesehatan. ${ }^{12}$

Dalam sebuah sistem dalam halnya organisasi sumber daya manusia merupakan elemen organisasi yang sangat penting dimana sumber daya manusia merupakan pilar utama sekaligus pengerak organisasi dalam upaya mewujudkan visi dan misinya. Oleh karena itu harus dipastikan sumber daya manusia harus dikelola dengan sebaik-baiknya agar dapat memberikan kontribusi secara maksimal. Sehingga membutuhkan sebuah pengelolaan secara sistimatis, dan terencana agar tujuan yang diinginkan dimasa sekarang dan masa yang akan datang dapat terlaksana dimana sering disebut sebagai manajemen sumber daya manusia.

Dalam pelaksanaan pengadaan alat kesehatan di RSUD Padang Pariaman, sumber daya manusia sangat penting untuk meningkatkan mutu pengadaan alat kesehatan di Rumah Sakit, maka disarankan agar RSUD Pariaman segera membenahi dengan menambah sumber daya manusia bidang perencanaan alat kesehatan dan mengirimkan atau melaksanakan pelatihan pengadaan barang/jasa. Dengan demikian diharapkan pelaksanaan pengadaan alat kesehatan di RSUD Padang Pariaman dapat terlaksana sesuai dengan tujuan pengadaan alat kesehatan dan dapat 
meningkatkan mutu pelayanan kesehatan di RSUD Padang pariaman.

\section{c. Dana}

Hasil penelitian yang menunjukkan bahwa untuk pendanaan dalam pelaksanaan pengadaan alat kesehatan sebahagian besar bersumber dari Anggaran Pendapatan Belanja Negara (APBN) melalui Kementerian Kesehatan dalam bentuk Dana Alokasi Khusus (DAK) dan dari Anggaran Pendapatan Belanja Daerah (APBD) dalam bentuk Dana Alokasi Umum (DAU) masih kurang.

Pengadaan alat kesehatan di RSUD Padang Pariaman adalah untuk peningkatan mutu pelayanan kesehatan di rumah sakit yang pada akhirnya menunjang peningkatan derajat kesehatan masyarakat. Pemerintah dan pemerintah daerah bertanggung jawab menyediakan rumah sakit dan mengatur penyebaran alat kesehatan berteknologi tinggi dan bernilai tinggi. ${ }^{1}$ Untuk itu pemerintah daerah Padang Pariaman sebagai pemilik rumah sakit bertanggung jawab dalam penyediaan alat kesehatan di rumah sakit dengan lebih meningkatkan anggaran biaya untuk pengadaan sarana prasarana di RSUD Padang Pariaman.

\section{d. Sarana Prasarana}

Pelaksanaan pengadaan alat kesehatan di RSUD Padang Pariaman belum didukung oleh sarana dan prasarana yang memadai. Proses kegiatan dilakukan dengan mengunakan sarana dan prasarana yang ada pada jabatan struktural yang melekat pada petugas pengadaan tersebut.

Sarana dan prasarana merupakan sumber daya penting dalam mendukung pelaksanaan tugas petugas yang bekerja pada suatu bidang pengadaan alat kesehatan di Rumah Sakit. Dengan sarana yang cukup, tentunya petugas akan bekerja dengan nyaman. Kenyamanan suasana kerja akan ikut meningkatkan prestasi kerja petugas. Prestasi kerja petugas yang bagus akan menunjang prestasi Rumah Sakit secara umum.

\section{Komponen Proses}

a. Perencanaan Penentuan Kebutuhan dan Prioritas Kebutuhan
Hasil penelitian pada perencanaan penentuan kebutuhan dimulai dari permintaan kebutuhan dari masing-masing instalasi atau user direkap dan dibahas dengan pimpinan, bidang pelayanan, bidang penunjang, tata usaha dan bidang perencanaan untuk menentukan prioritas kebutuhan rumah sakit. untuk dana DAK diajukan usulan prosposal oleh bidang penunjang medik ke bidang perencanaan untuk penyesuaian prioritas dengan menu alat kesehatan yang tersedia pada menu DAK. Apabila prioritas kebutuhan tidak tersedia pada menu DAK maka dialihkan pada kebutuhan yang lain yang ada pada menu DAK tersebut.

Penilaian kebutuhan (need assessment) adalah proses untuk menentukan dan mengatasi kesenjangan antara situasi atau kondisi saat ini dengan situasi atau kondisi yang diinginkan. Penilaian kebutuhan peralatan medis pada dasarnya bertujuan untuk pemenuhan standar peralatan medis sesuai kemampuan/klasifikasi rumah sakit, pengantian peralatan medis dan pengembangan pelayanan kesehatan sesuai kebutuhan masysarakat atau perkembangan teknologi. ${ }^{12}$

Perhitungan peralatan medis untuk pemenuhan kebutuhan sesuai standart, jenis dan jumlah peralatan medis harus memperhatikan kemampuan layanan berdasarkan klsifikasi rumah sakit dan ketersedian jumlah kopetensi SDM yang di persyaratkan ketersedian sarana ruangan untuk penempatan peralatan dan volume pemamfaatan pelayanan kesehatan.

Perencanaan peralatan medis di fasilitas pelayanan kesehatan membutuhkan keterlibatan tenaga teknis peralatan medis, tenaga medis, keperawatan, tenaga teknis sarana prasarana dan manajemen. Perencanaan peralatan medis tertentu membutuhkan perencanaan kebutuhan ruangan untuk penempatan peralatan medis, tenaga medis dan jumlah pasien serta instalasi medik meliputi kelistrikan, gas medik, dan sarana lainya. ${ }^{12}$

Agar pelaksanaan pengadaan alat kesehatan di RSUD Padang Pariaman terutama dalam tahapan perencanaan penentuan kebutuhan dan prioritas kebutuhan hendaknya RSUD Padang 
Pariaman membemtuk Tim perencanaan, membuat SOP pelaksanaan penilaian kebutuhan peralatan medis, melibatkan tenaga teknik eletromedik, bidang sarana prasarana rumah sakit. Dan untuk pengadaan alat kesehatan yang mengunakan anggaran APBN atau DAK pemilihan menu alat kesehatan pada aplikasi alat kesehatan DAK tetap berpedoman pada prioritas kebutuhan alat yang telah ditetapkan dan tidak memilih menu yang bukan termasuk prioritas kebutuhan, karena tidak akan efektif dalam pemamfaatan atau sama sekali belum dapat di mamfaatkan. Untuk alat kesehatan yang menjadi prioritas kebutuhan tetapi tidak ada pada menu DAK maka bidang perencanaan mengkembalikan lagi pada bedang pelayanan medik untuk diusulkan pada tahun berikutnya atau mengunakan sumber anggaran lainya.

\section{b. Pengadaan Alat Kesehatan}

Pengadaan adalah kegiatan pelaksanaan pemilihan penyedia pengadaan yang dilakukan oleh panitia pengadaan untuk memenuhi kebutuhan user. Hasil penelitian proses pelaksanaan pemilihan penyedia pengadaan alat kesehatan di RSUD Padang Pariaman dilaksanakan dengan $E$ Purchasing melalui E-caatalogue.

Hasil penelitian proses pelaksanaan pengadaan alat kesehatan di RSUD padang Pariaman dilaksanakan dengan pemilihan penyedia penunjukan langsung melalui E-Purchasing. Hal ini telah sesuai karena alat kesehatan merupakan alat yang sudah terstandar dan juga kewajiban Kementerian, Lembaga, Dinas dan Instansi melakukan E-Purchasing terhadap barang/jasa yang sudah dimuat dalam sistem katalog elektronik sesuai dengan kebutuhan Kementerian, Lembaga, Dinas dan Instans. ${ }^{13}$

Hasil penelitian ini sama dengan penelitian menyatakan bahwa dalam melakukan pengadaan obat dan alat kesehatan di RSUD Kabupaten Sukoharjo secara keseluruhan sudah memenuhi ketentuan-ketentuan hukum yang berlaku yakni Perpres Nomor 4 Tahun 2015, Perka LKPP dan peraturan internal rumah sakit lainnya. ${ }^{9}$

Pengadaan barang/jasa pemerintah dapat juga dilakukan secara eletronik. Pengadaan barang/jasa secara eletronik dilakukan dengan cara
E-Tendering atau E-purchasing. ${ }^{14}$ Sementara itu $\mathrm{K} / \mathrm{L} / \mathrm{D} / \mathrm{l}$ wajib melakukan E-purchasing terhadap barang/jasa yang sudah dimuat dalam sistim katalog eletronik sesuai kebutuhan. ${ }^{13}$ Metode pelelangan lebih efisien digunakan untuk pengadaan yang bernilai besar dan beresiko tinggi karena pekerjaan tersebut belum terstandarisasi, sedangkan untuk barang yang sudah terstandart seperti alat kesehatan metode E-catalogue lebih tepat digunakan. Khusus untuk barang bernilai dan beresiko kecil yang belum memiliki standar sehingga tidak bisa dimuat dalam E-catalogue pengadaan barang/jasa lebih efisien dengan spot purchasing atau pengadaan langsung. ${ }^{15}$

\section{c. Penerimaan Pengadaan alat Kesehatan}

Penerimaan adalah penilaian atau pemeriksaan yang dilakukan oleh panitia penerima/pemeriksa dalam pengadaan alat ksehatan di RSUD Padang Pariaman. Hasil penelitian terhadap penerimaan pelaksanaan pengadaan alat kesehatan di RSUD Padang Pariaman adalah penerimaan dilakukan oleh tim penerima barang yang beranggotakan lima orang, satu orang dari KTU, satu orang dari ekbang, satu orang tenaga eletromedik dan dua orang dari farmasi, pemeriksaan berpedoman pada surat pesanan atau kontrak dan dilakukan instalisasi alat yang membutuhkan instalisasi, pemeriksaan administrasi dan uji fungsi alat.

Keanggotaan panitia/pejabat penerima pengadaan alat kesehatan terdiri dari unsur teknik, pengguna (user), manajemen dan petugas administrasi barang dan Proses penerimaan pengadaan alat kesehatan melalui tahapan pemeriksaan fisik alat atau adminstrasi, uji fungsi alat, pelatihan operator dan uji coba alat. ${ }^{12}$

Hasil penelitian keanggotaan tim penerima/pemeriksa terdiri dari lima orang yakni satu dari manajemen, satu dari tenaga teknis eletromedik, satu dari ekbang dan dua orang dari farmasi. Dalam keanggotan penerima dan pemeriksa sudah melibatkan unsur teknis eletromedik, tetapi tidak melibatkan tenaga administrsi barang dan pengguna (user). 
Hasil penelitian dalam penerimaan dilakukan instalisasi alat, pemeriksaan fisik atau administrasi dan melakukan uji fungsi alat. Akan tetapi tidak melakukan uji coba alat dan pelatihan operator oleh penyedia.

Untuk mendapatkan alat kesehatan yang sesuai dengan kebutuhan rumah sakit, user dan dapat termanfaatkan langsung dalam pelayanan kesehatan tim penerima/pemeriksa alat kesehatan tersebut harus memastikan alat kesehatan tersebut sudah di instalisasi oleh penyedia, melakukan pemeriksaan administrasi, pemeriksaan uji fungsi alat, uji coba alat dan pelatihan operator.

\section{Komponen Output}

Output adalah kumpulan bagian/elemen yang dihasilkan dari berlangsungnya proses dalam sistem. Output yang diharapka adalah kesesuaian penyedian pengadaan alat kesehatan dengan kebutuhan rumah sakit, user dan dapat dimanfaatkan langsung dalam pelayanan kesehatan di RSUD Padang Pariaman.

Hasil penelitian pelaksanaan penyedian pengadaan alat kesehatan di RSUD Padang Pariaman belum sepenuhnya sesuai dengan kebutuhan rumah sakit, user dan masih adanya alat kesehatan yang belum dimanfaatkan dalam pelayanan kesehatan di RSUD Padang Pariaman. Hal ini disebakan karena masih ada alat kesehatan yang disediakan bukan permintaan user, pengadaan alat yang tidak lengkap, ruang penempatan alat yang belum tersedia, ketidak siapan sarana penunjang lainnya seperti daya listrik dan belum adanya sumber daya manusia yang akan mengoperasikan.

Pengadaan yang tidak sesuai dengan kebutuhan dapat menyebabkan tidak maksimal dalam pemanfaatan atau belum dapat dimanfaatkan sama sekali oleh user dalam pelayanan kesehatan. Rumah Sakit harus selalu melakukan pembenahan dengan mengevaluasi proses pengadaan alat kesehatan dengan memperhatian pada setiap komponen yang mendukung proses pengadaan mulai dari input berupa, kebijakan (SOP), SDM, dana sarana dan prasarana, serta proses perencanaan, pengadaan dan penerimaan agar kedepannya pelaksanaan pengadaan alat kesehatan menjadi lebih efektif dan efisien.

\section{KESIMPULAN}

Proses pengadaan alat kesehatan di RSUD Padang Pariaman dilihat pada pendekatan sistim pada komponen input kebijakan (SOP), SDM, dana dan sarana belum sepenuhnya memenuhi syarat, pada komponen proses belum sesuai dengan Pedoman Pengelolaan Peralatan Kesehatan di Fasilitas Pelayanan Kesehatan; 2015. Direktorat Bina Pelayanan Penunjang Medik dan Sarana Kesehatan dan Pada komponen output pelaksanaan pengadaan alat kesehatan di RSUD Padang Pariaman belum sepenuhnya sesuai dengan kebutuhan rumah sakit dan user.

\section{SARAN}

Agar pelaksanaan pengadaan alat kesehatan di RSUD Padang Pariaman berjalan dengan baik dan dapat mencapai tujuan sebagaimana yang diharapkan, maka disarankan kepada semua pihak manajemen yang terkait dengan proses pengadaan alat kesehatan segera membenahi semua komponen yang berkaitan dengan pelaksanaan pengadaan alat kesehatan mulai dari komponen input (kebijakan, sumber daya manusia, dana dan sarana prasarana) dan komponen proses (perencanaan, pengadaan dan penerimaan). Bagi peneliti lanjutan perlunya penilitian lebih lanjut tentang pemanfaatan alat kesehatan di RSUD Padang Padang Pariaman.

\section{DAFTAR PUSTAKA}

1. DPR RI. Undang-Undang Republik Indonesia Nomor 44 Tahun 2009. Tentang Rumah Sakit. Jakarta: DPR RI; 2009.

2. Kementerian RI. Peraturan Menteri Kesehatan Kesehatan Republik Indonesia Nomor 56 Tahun 2014.Tentang Klasifikasi dan Perizinan Rumah Sakit. Jakarta: Kemenkes RI; 2014

3. Bowersox D J. Manajemen Logistik, Jakarta: Bumi Aksara; 2006. P. 3-12.

4. Aditama T Y. Manajemen Administrasi Rumah Sakit. Jakarta: Uneversitas Indonesisa; 2003. P. 109-120

5. RSUD Padang Pariaman. Profil RSUD Padang Pariaman Tahun 2017. Bidang Penunjang Medis. Parit Malintang; 2017. 
6. Febriawati H. Manajemen Logistik Rumah Sakit.Yogyakarta: Gosyen Publishing; 2013. P. 5-46.

7. Kemenkes RI. Keputusan Menteri Kesehatan Nomor 04 Tahun 2003. Tentang Kebijakan dan Strategi Desentralisasi Bidang Kesehatan. Jakarta: Kemenkes RI; 2003.

8. Kemenkes RI. Peraturan Menteri Kesehatan Republik Indonesia Nomor 84 Tahun 2014. Tentang Petunjuk Teknis Pengunaan Dana Alokasi Khusus Bidang Kesehatan. Jakarta: Kemenkes RI; 2014.

9. Kurniawan D. G. Model Transaksi Pengadaan Obat dan alat Kesehatan Studi Transaksi PT.Enseval Putera Megatranding,TBK.Cabang Surakarta dengan RSUD Kabupaten Sukoharjo. Surakarta: Tesis Program Pascasarjana Universitas Muhammadiyah Surakarta; 2017.

10. Kemen PAN RI. Kementerian Pendayagunaan Aparatur Negara dan Reformasi Birokrasi. Pedoman Penyusunan Standar Operasional Prosedur Administrasi Pemerintahan. Jakarta: Kemen PAN RI; 2012.

11. Presiden RI. Peraturan Presiden Republik Indonesia Nomor 54 Tahun 2010. Tentang Pengadaan Barang/Jasa Pemerintah. Jakarta: Presiden RI; 2010.

12. Kemenkes RI. Direktorat Bina Pelayanan Penunjang Medik dan Sarana Kesehatan: Pedoman Pengelolaan Peralatan Kesehatan di Fasilitas Pelayanan Kesehatan 2015. Jakarta: Kemenkes RI; 2015.

13. Presiden RI. Peraturan Presiden Republik Indonesia Nomor 4 Tahun 2015. Tentang Perubahan Keempat Atas Peraturan Presiden Nomor 54 Tahun 2010 pengadaan Barang/Jasa Pemerintah. Jakarta: Presiden RI; 2015.

14. Presiden RI. Peraturan Presiden Republik Indonesia Nomor 70 Tahun 2012. Tentang Perubahan Kedua Atas Peraturan Presiden Nomor 54 Tahun 2010 pengadaan Barang/Jasa Pemerintah. Jakarta: Presiden RI; 2012

15. Arfani N. Efisiensi Pengadaan Barang/Jasa dengan E-Catologe.Jurnal Pengadaan Lembaga Kebijakan Pengadaan Barang/Jasa Pemerintah (LKPP). 2015; 4(1):38-50. Diakses 18 Juni 2017. 